\title{
Preliminary report of the 2019 excavation at Švédův Stůl Cave in the Moravian Karst
}

\author{
Předběžná zpráva o výzkumu jeskyně Švédův stůl \\ v Moravském krase v roce 2019
}

- Ladislav Nejman*, Philip Hughes, Marjorie Sullivan, Duncan Wright, Amy Mosig Way, Nicholas Skopal, Ondřej Mlejnek, Petr Škrdla, Lenka Lisá, Matěj Kmošek, Miriam Nývltová Fišáková, Miroslav Králík, Petr Neruda, Zdeňka Nerudová, Antonín Přichystal -

KEYWORDS:

Moravian karst - Neandertals - re-excavation - spoil-heap geochemical signals

\section{ABSTRACT}

Švédìv Stůl Cave in the Moravian Karst has been excavated several times

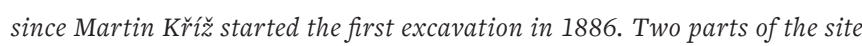
were re-excavated in 2019. The primary aim was to conduct classical as well as innovative and experimental sedimentological and geoarchaeological investigations of sediments from the discarded spoil heap outside the cave entrance (trench $C-D$ ). Intact sediments with a small number of lithic artefacts and a large number of animal bones were also excavated during the 2019 excavation (trench $A-B$ ) located under the trench excavated by Bohuslav Klima's team in the 1950s. An attempt is being made using $p X R F$, benchtop $E D-X R F$ and ITRAX techniques to link some of the sedimentary material in the spoil heap $(C-D)$ with the stratified sediments in trench $A-B$. Animal bones and lithic artefacts were found in both trenches. Numerous samples were collected for geoarchaeological, palaeoenvironmental and dating analyses and the results will be published in upcoming publications.

\section{* Corresponding author - E-mail address: Inejman81@gmail.com}

https://doi.org/10.47382/pv0611-01

Copyright ( $\odot 2020$ Czech Acad Sci, Inst Archaeology Brno, and the authors.

Competing interests: The authors have declared that no competing interests exist.

\section{Introduction and history of excavation}

Švédův Stůl Cave is located at $49^{\circ} 14^{\prime} 43.4^{\prime \prime} \mathrm{N} 16^{\circ} 44^{\prime} 51.9^{\prime \prime} \mathrm{E}$ in the southern part of the Moravian Karst, near the village of Ochoz u Brna, and approximately $10 \mathrm{~km}$ north-east of the city of Brno (Moravia, Czech Republic) (Fig. 1). It is situated $11 \mathrm{~m}$ above the valley of Říčka Creek and $334 \mathrm{~m}$ above sea level (Valoch et al. 2002). The cave has been formed in Devonian light-grey limestone of the Vilémovice Formation and has been known to people since ancient times. The cave was much larger during the Palaeolithic period before major episode of roof collapse occurred, probably in the mid-Holocene (Klíma 1962). According to legend, during the siege of Brno in 1645 , the Swedish army camped outside this cave and used a large limestone block (probably a section of the collapsed roof) as a 'table' for dining (the name 'Švédův Stůl' translates to 'Swedish Table').

The earliest published description of the cave was provided by Florián Koudelka in 1883 (Koudelka 1883) with first major excavations conducted by Martin Kř́ž in 1886-1887. In $1905 \mathrm{Ka}^{-}$ rel Kubasek (geology student) recovered part of a human

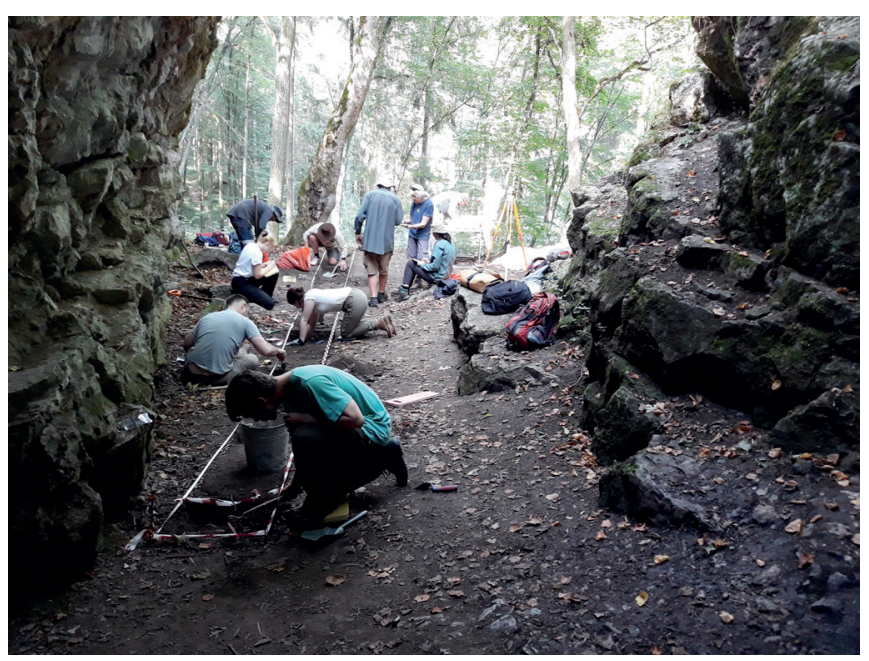

Fig. 1. The cave, looking north from just inside the entrance across the area previously excavated in 1953-1955 (Klíma 1962). Those excavations extended out to the large tree just beyond the excavation team. The 1953-1955 spoil heap is just beyond the yellow tripod. The 2019 trench (marked by pale coloured tape) is aligned approximately along the section shown in Klíma (1962, Fig. 6) reproduced in Figure 6 below. Photo by L. Nejman.

Obr. 1. Jeskyně, pohled ze vstupní části severním směrem na plochu zkoumanou Klímou v letech 1953-1955 (Klíma 1962). Tyto výzkumy zasahovaly až ke stromu, který je vidět za pracovníky. Materiál z výzkumů v letech 1953-1955 byl deponován na výsypce za žlutým stativem. Výzkum v roce 2019 (označen barevným páskem) sleduje přibližně profil publikovaný Klímou (1962, obr. 6) a reprodukovaný níže na obrázku 6. Foto L. Nejman. 
Preliminary report of the 2019 excavation at Švédův Stůl Cave in the Moravian Karst • Nejman, L., Hughes, P., Sullivan, M., Wright, D., Way, A. M., Skopal, N., Mlejnek, O., Škrdla, P., Lisá, L., Kmošek, M., Nývltová Fišáková, M., Králík, M., Neruda, P., Nerudová, Z., Přichystal A. Přehled výzkumů 61/1, 2020 • 11-19

mandible in the rear part of the cave but did not publish any information about his excavation (Oliva 2017). This mandible was classified as Neanderthal and published by Anton Rzehak the following year (Rzehak 1906), which increased interest in this cave amongst the scientific community and wider public. Another excavation by Martin Kř́ž in 1908 was followed by multiple field-seasons of excavation inside the cave as well as outside (although the outside area was potentially part of the cave interior before the major roof collapse) in 1953-1955. Detailed information was published in a lengthy monograph with Palaeolithic cultural materials classified as Mousterian, Aurignacian and Magdalenian (Klíma 1962). None of the absolute dating methods used today were available at that time so no dates exist for any of the contexts at this site. Other documented and undocumented excavations by archaeologists and amateurs alike took place at different times throughout the $20^{\text {th }}$ century. The last known controlled excavation took place in the 1980s inside the cave (see Vaňura 1983).

It has been stated frequently that no in situ sediments remain inside the cave (e.g. see Vaňura 1963; Oliva 2017). In situ sediments were however thought to exist in the area outside the cave entrance where Bohuslav Klíma excavated a $370 \mathrm{~cm}$ deep section in 1953-1955 (Pelíšek 1962 - in Klíma 1962), and which was probably part of the cave interior before the roof collapse. For example, Figure 6 in Klíma $(1962,23)$ appears to show that bedrock was not reached at the very front of the excavation. (Fig. 2).

A Czech-Australian team conducted a new excavation at Švédův Stůl Cave from 28 August to 12 September 2019. Participating institutions include the Archaeology Institute in Brno and the Moravian Museum. The excavation was planned and carried out with Australian researchers from the University of
Sydney (Sydney), the Australian National University (Canberra) and Flinders University (Adelaide).

In this paper we report on this re-excavation of Švédův Stůl Cave. Following successful excavation of a large spoil pile at Vogelherd Cave in south-western Germany from 2005 to 2012 (Conard et al. 2015, 207-221) and Feldhofer Cave (Neander Valley) in western Germany (Schmitz et al. 2002) we were interested to assess whether similar archaeological potentials may exist for these features in the Moravian Karst. Preliminary results are provided for this excavation, also for intact sediments located outside the front of this cave.

\section{Research aims in 2019}

The goal of the 2019 research was twofold. The primary objective was re-excavation of a small section of the dump pile or spoil-heap, formed mainly by the 1953-1955 excavations (Fig. 3). This might facilitate recovery of cultural materials missed during the original excavations, also testing the hypothesis that scientific analysis of sediments within the spoil-heap (including those adhering to excavated artefacts) may match those previously described and/or sampled in situ during the original excavations. The second objective was to locate in situ sediments, should these survive outside the cave, and use this to bolster cultural and palaeoenvironmental understanding of this site.

In 2019 (in line with these aims), excavations targeted a large conical spoil heap (Square $\mathrm{C}-\mathrm{D}$ ), also an area at the front of the cave (Square A-B) shown in Figure 4. It was anticipated that the former would provide a suitable section (and sediment samples) to test whether a linkage exists between the spoil heap and in situ samples. We will now examine methodology, methods and preliminary results (including faunal analysis) arising from the 2019 excavations.

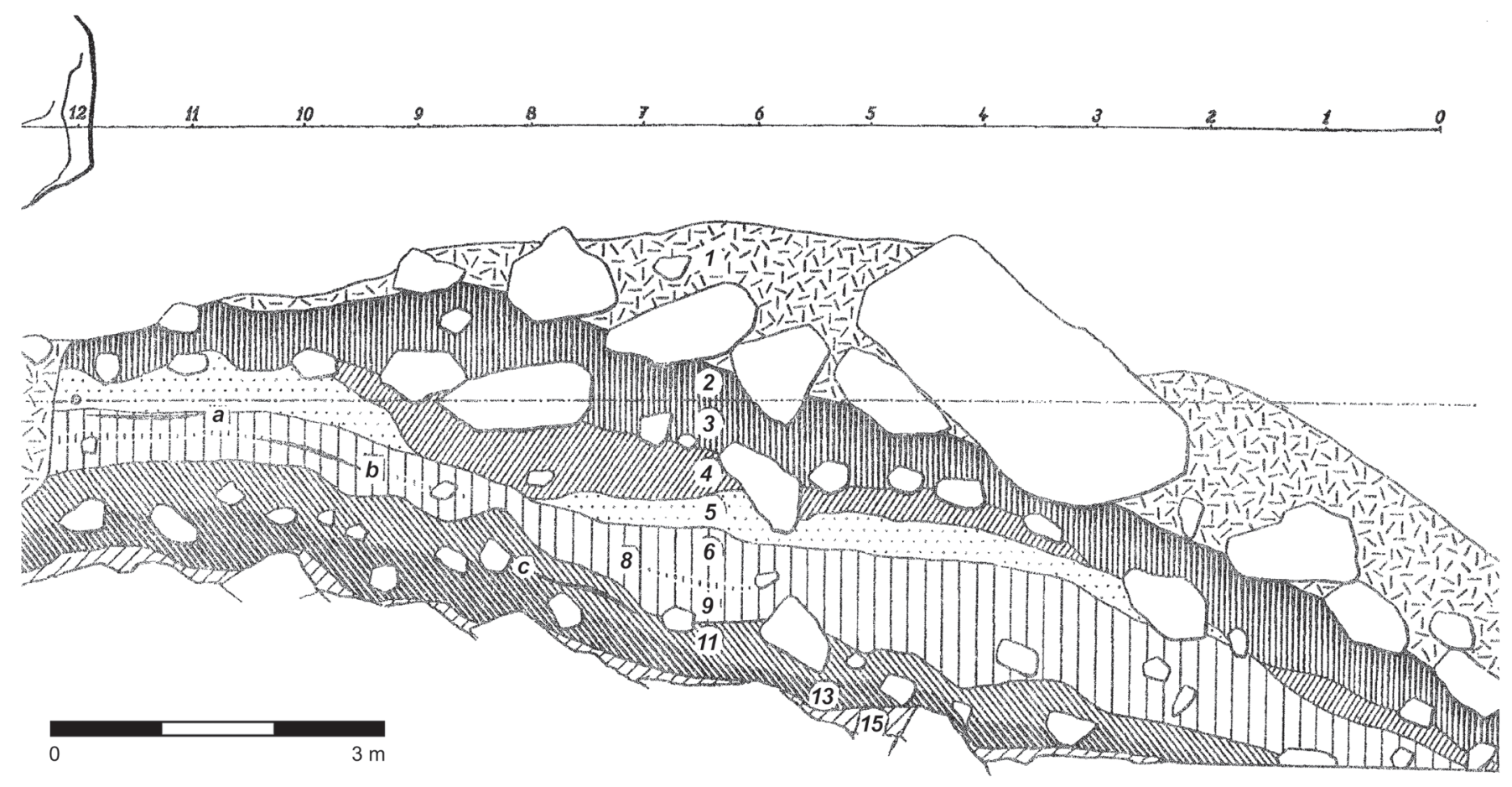

Fig. 2. Klíma (1962) Fig. 6, which appears to show that bedrock was not reached at the front of the excavation (bottom of section, straight line on the right). The levels at which various phases of occupation were found are shown as: a - Magdalenian, b - Aurignacian, c - Mousterian. Reproduced from Klíma 1962 , Fig. 6.

Obr. 2. Klímův (1962) obr. 6., který naznačuje, že v přední části výzkumu nebylo dosaženo podloží (rovná čára vpravo dole). Úrovně jednotlivých sídelních horizontů jsou označeny písmeny: a - magdalénien, b - aurignacien, c - moustérien. Reprodukce z Klíma 1962, Fig. 6. 
Preliminary report of the 2019 excavation at Švédův Stůl Cave in the Moravian Karst • Nejman, L., Hughes, P., Sullivan, M., Wright, D., Way, A. M., Skopal, N., Mlejnek, O., Škrdla, P., Lisá, L., Kmošek, M., Nývltová Fišáková, M., Králík, M., Neruda, P., Nerudová, Z., Přichystal A. Přehled výzkumů 61/1,2020 • 11-19

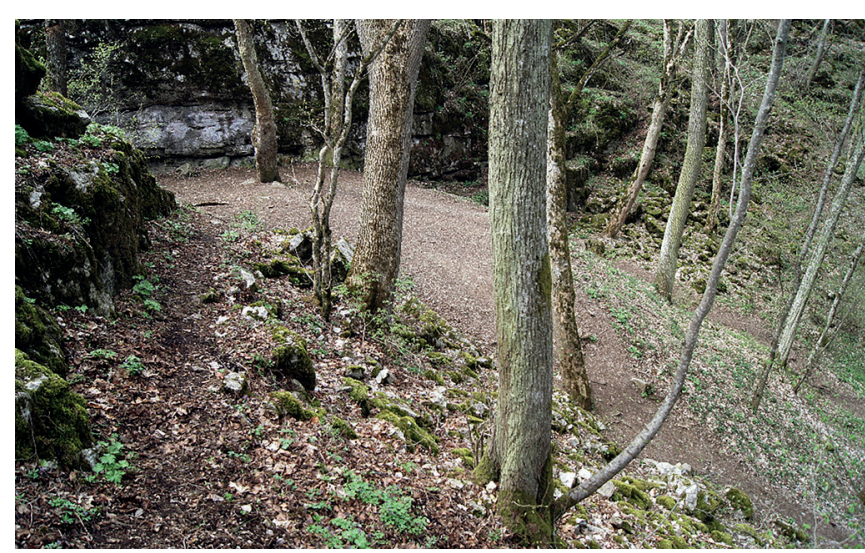

Fig. 3. The spoil heap in front of the cave. Photo by P. Škrdla.

Obr. 3. Výsypka před jeskyní. Foto P. Škrdla.

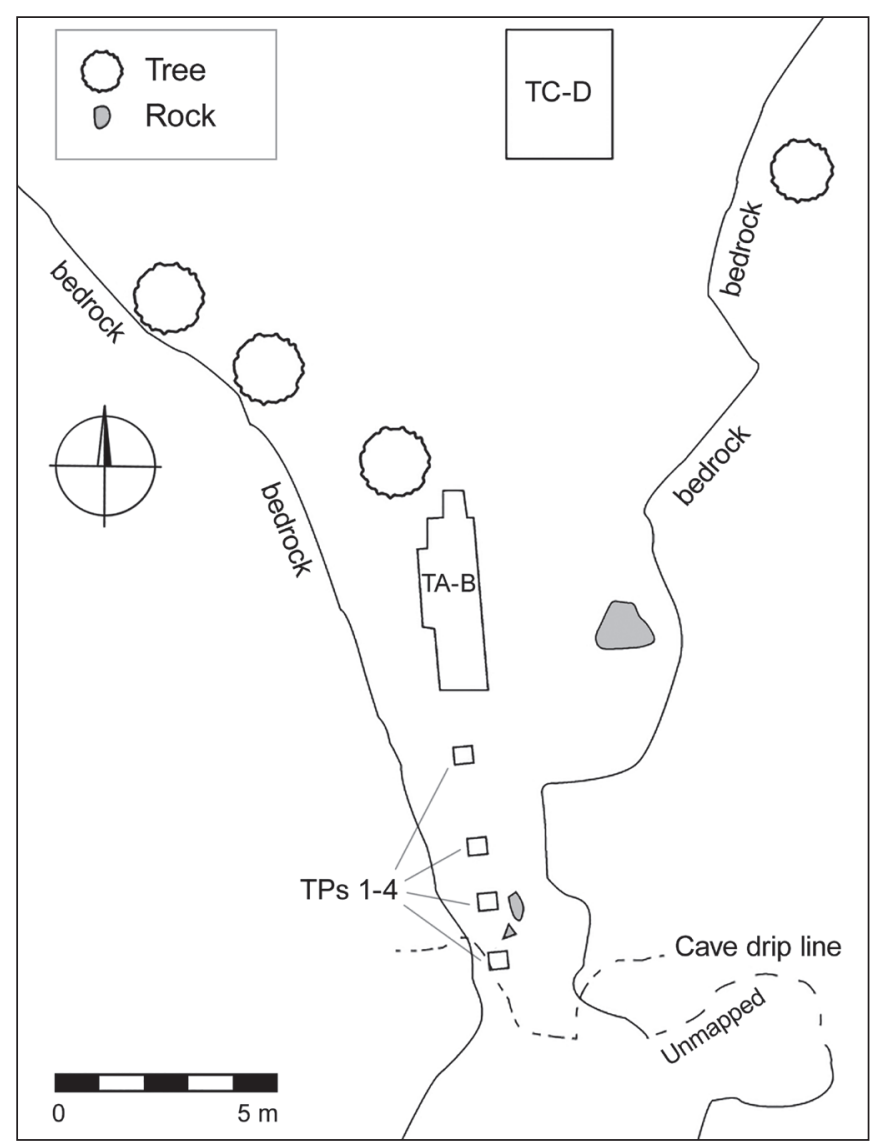

Fig. 4. Ground plan of the Švédův Stůl Cave entrance area with the position of the two 2019 excavation pits. Drawn by D. Wright.

Obr. 4. Půdorys vstupní části Švédova stolu s umístěním sond v roce 2019. Kresba D. Wright.

\section{The role and relevance of the spoil heap for Palaeolithic archaeologists}

The utility of excavating spoil heaps at sites excavated in the early days of archaeology has been demonstrated on several occasions. For example, in 2005-2012, 74 years after the original excavation, Prof. Nicholas J. Conard conducted a systematic excavation (including wet-sieving) of a large spoil pile at Vogelherd Cave in south-western Germany. Many symbolic objects (figurines, fragments of figurines and personal ornaments), also stone artefacts and faunal remains were recovered from the discarded spoil in front of the cave (see e.g. Dutkiewicz 2015). At Feldhofer Cave (western Germany) where the Neanderthal type specimen was discovered in 1856, a re-excavation of the dumped sediments took place in 1997 and 2000 yielding 62 human skeletal fragments and many Palaeolithic artefacts and faunal material (Schmitz et al. 2002). The re-excavation of Vogelherd Cave and Feldhofer Cave and their far-reaching results partly inspired our work at Švédův Stůl.

It was common practice during $19^{\text {th }}$ and early $20^{\text {th }}$ century excavations of Palaeolithic sites in in Europe (including Švédův Stůl) and most other parts of the world to excavate by stratigraphic layer, dumping wheelbarrow loads of sediments on to a growing spoil-heap. Field methods rarely involved wet-sieving of excavated sediments and therefore it is reasonable to expect that (like Vogelherd and Feldhofer caves) smaller finds may have been missed, discarded on the dump pile along with the sediment. It might also be possible (with a number of provisos) to observe single deposition events in which wheelbarrow loads of related sediments may survive in 'chunks' or layers. It might also be expected that original sediments adhering to bones or artefacts may be linked to in situ sediments sampled during previous excavations (some of which are stored in the Moravian $\mathrm{Mu}^{-}$ seum). Should such attempts be successful, the original stratigraphic and/or cultural context of some of the finds could potentially be determined, or approximated.

Klíma (1962) reported visible differences between sedimentary layers removed during excavation of Švédův Stůl (see for example Fig. 2). These included limestone-rich layers from rockfall, pale ashy, dark organic or phosphatic bone-rich layers from human or other faunal occupation, silty inorganic reddish to yellowish layers of windblown or water-redeposited sediments derived mainly from loess. While bioturbation and other post-depositional disturbance may occur, it was considered plausible that some layers or lenses (associated with deposition of wheelbarrow loads of excavated sediment) may survive in the spoil heap. These may be visible in the stratigraphic section or identifiable through differing chemical signals in the form of key 'trace' elements or element ratios. We now explore methods by which we might unravel these complex deposition events.

\section{Methods and analyses}

Geochemical analyses are central to our project methodology and therefore it is important to provide some background information. Current practice for elemental analysis of sediments is to use X-radiation, particularly X-ray fluorescence (XRF). X-ray fluorescence provides high-quality elemental composition data, but some of the traditional analytical procedures used are time-consuming and may destroy samples when they include the need for crushing. Recently, portable XRF scanning instruments (pXRF) have become widely used among others for rock chemical analysis, or to identify unlabelled chemical powders to ascertain their potential harmfulness (for example to identify agricultural chemicals potentially containing persistent organic pollutants, or explosives or poisons). These pXRF scanners are suitable mainly for fast non-destructive analysis. They are available with a range of capacities (reflecting their quality and cost) but all are limited in the accuracy, number and types of elements they can isolate, especially among the light elements. The pXRF analysis has the potential to be very useful in preliminary stages of archaeological investigation.

Field elemental pXRF analysis were done by handheld spectrometer DELTA Professional. It was used by MK from the Institute of Archaeology in Brno to ascertain the composition of the limestone in which the cave is formed and to undertake preliminary 
Preliminary report of the 2019 excavation at Švédův Stůl Cave in the Moravian Karst • Nejman, L., Hughes, P., Sullivan, M., Wright, D.,

Way, A. M., Skopal, N., Mlejnek, O., Škrdla, P., Lisá, L., Kmošek, M., Nývltová Fišáková, M., Králík, M., Neruda, P., Nerudová, Z., Přichystal A.

Přehled výzkumů 61/1, 2020•11-19

characterisation of the sediments sampled from layers and lenses exposed during the excavations and the 11 samples from the Klíma (1962) excavations held by the Moravian Museum. These data would also guide selection of which element ratios should be investigated using benchtop ED-XRF and ITRAX, linking potential lenses of original sediment in the discard pile with identified in situ sediments and/or with remnant sediments adhering to bones or artefacts recovered from the discard pile.

The Institute of Archaeology in Brno possesses a benchtop ED-XRF ElvaX Pro analyser that provides more accurate analysis of wider range of elements (relevant results even for sodium and magnesium) than pXRF spectrometers. The Australian Nuclear Science and Technology Organisation (ANSTO) in Sydney, Australia maintains an ITRAX automated multi-function core scanning instrument (see Croudace et al. 2006), which is capable of non-destructively recording optical, radiographic and elemental variations from sediment half cores and other contained samples and collects optical and X-radiographic (including XRF) images to provide rapid high-resolution elemental profiles. Our intention was to identify chemical signals of particular sediments using the capacity of the ITRAX technique in this project in comparison with results from pXRF and benchtop ED-XRF.

Through the combined application of pXRF, benchtop ED-XRF and ITRAX our intention in the 2019 season was to first establish the chemical signals of excavated sediments from the discard pile, the in situ sediments and (using pXRF only) the 11 original samples from the Moravian Museum, and second, the capacity of these instruments to link potential lenses of original sediment in the discard pile with identified in situ sediments and/or with remnant sediments adhering to bones or artefacts recovered from the discard pile. Also, if the dumped spoil sediments contain clear lenses of identifiable sediment, especially if these lenses contain bones or stone artefacts, there would be a clear guide to provenance.

Our proposed field method for linking the original fill profile to sediment 'chunks' or layers in the dumped spoil sediments was as follows: assuming we are able to gain access to an exposed section of the surviving intact deposit we would collect samples of these layers from exposed vertical section(s) and cut a 'core' or composite profile from the remnant profile that could be used as a 'control' core, to run through an ITRAX scan. Our hope with this exercise was to obtain a range of sedimentary chemical (mainly metal) elements/ratios that might characterise the layers. Recording the sediment composition at fixed intervals, we hoped to match those data with the wall section(s) stratigraphy, or the stratigraphy described by Klíma (1962). As we excavated into the spoil heap we proposed to take 'sediment cores' in an exposed face of our excavations, with close attention to the nature of the sediments from where artefacts were recovered, or we would create a 'core' by stacking sediment-box samples from layers that did and did not contain archaeological materials. If we then ran that second 'core' from the spoil-heap excavations through ITRAX, we hoped to be able to match (at a broad level at least) sediment packages to specific layers of the cave fill. In addition to ITRAX, pXRF scanning of the sediments adhering to bones and stone artefacts could produce useful results given any sharp differences in the characteristics of the fine textured matrices of the various archaeological layers expected.

This method is based on the concept that it might be possible to find a key marker element, a rare trace-element, or a two-element ratio, for a specific layer and then link material from the discard pile (which has lost its original context), with material in the in situ sediments (with a known stratigraphic context). It was anticipated that a sediment layer dominated by roof-fall (limestone) could be expected to be high in calcium and low in other elements. Iron occurs commonly in rocks and derived sediments in association with manganese and arsenic, so predominantly washed-in layers would be expected to show iron ( $\mathrm{Fe})$, calcium (Ca) (and perhaps magnesium $[\mathrm{Mg}]$ ) as the main elements, with possible other persistent elements (e.g. manganese $[\mathrm{Mn}]$, zinc $[\mathrm{Zn}]$, arsenic $[\mathrm{As}]$, lead $[\mathrm{Pb}]$ ) co-varying with them. Windblown or subsequently water-transported loess-like deposits should contain key trace elements such as zinc ( $\mathrm{Zn})$, tin (Sn), zirconium ( $\mathrm{Zr}$ ), beryllium (Be) and dominant silica ( $\mathrm{Si}$ ). Human and faunal occupations also leave chemical traces. Relatively high values for phosphorus (P), nitrogen (N) and carbon (C) would be expected in such layers (from dung or stabling material) commonly with sulphur (S) and potassium (K).

The osteological material was identified at the site during the excavation. After excavation, the osteological material was transferred to the osteological laboratory at the Institute of Archaeology of the Academy of Sciences of the Czech Republic, Brno, by MN-F. For taxonomic and anatomical determination of the recovered bones, MN-F's extensive private comparative osteological collection was used for comparative analysis. Literature consulted included osteological handbooks and atlases (Hue 1907; Lavocat 1966; Pales, Lambert 1971; Schmid 1972; France 2009). The minimum number of individuals (MNI) of each species was determined using the methodology of Chaplin (1971). The estimation of biological age was based on the
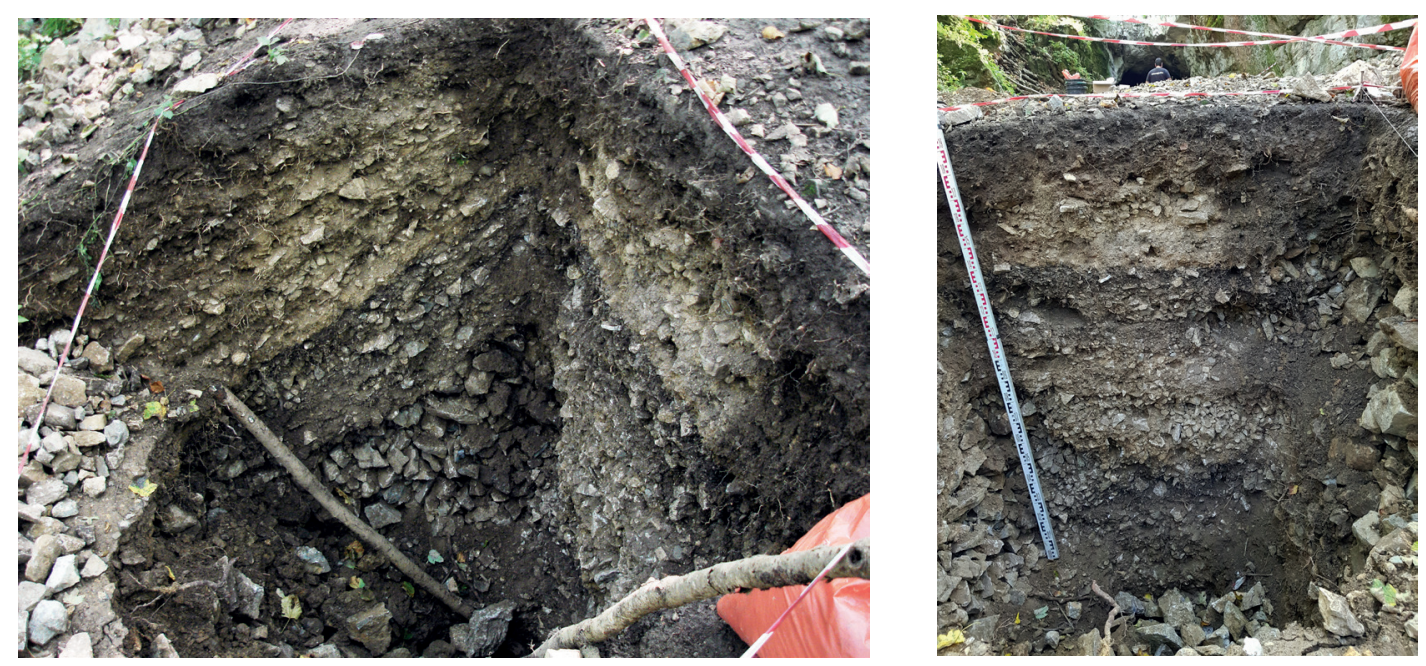

Fig. 5. Southern section wal of Kříž (?) and Klíma spoil heap. Photo by D. Wright. Obr. 5. Jižní profil sondy ve výsypce materiálu z Kř́ižových (?) a Klímových výzkumů. Foto D. Wright. 
Preliminary report of the 2019 excavation at Švédův Stůl Cave in the Moravian Karst • Nejman, L., Hughes, P., Sullivan, M., Wright, D., Way, A. M., Skopal, N., Mlejnek, O., Škrdla, P., Lisá, L., Kmošek, M., Nývltová Fišáková, M., Králík, M., Neruda, P., Nerudová, Z., Přichystal A. Přehled výzkumů 61/1,2020 • 11-19

$\mathrm{C} 13$

C14
C16
C18

C19

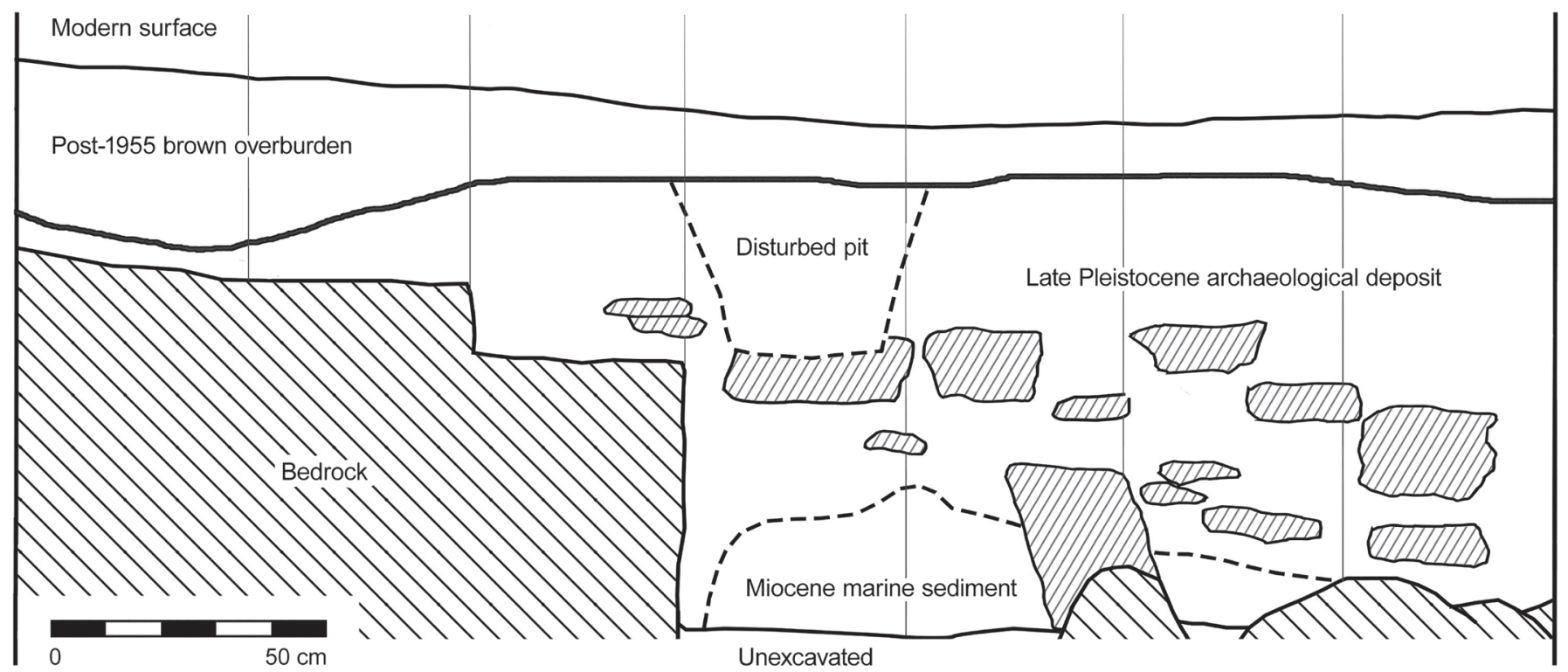

Fig. 6. Western section of excavation squares $\mathrm{C} 13$ to $\mathrm{C} 19$. Drawn by $\mathrm{A}$. Way and $\mathrm{P}$. Hughes. Obr. 6. Západní profil výzkumu ve čtvercích C13 až C19. Kresba A. Way and P. Hughes.

developmental stage of long bones, and dentition (Kurtén 1958; 1976; Habermehl 1985). Biological age estimation of adult individuals was also based on the degree of dentition abrasion (Kurtén 1958). Pathological changes and postmortem taphonomic damage were observed on some of the bones. Most frequent examples include predator bite marks and gnawing, or rodent gnawing (Binford 1981; Lyman 1994).

\section{Excavation methods (August-September 2019)}

To sample the discarded sediments a test trench (C-D) was excavated into the northern edge of the spoil heap (as it slopes down to the Ríčka Creek valley). This was $2 \mathrm{~m}$ in length, excavated to a depth of $204 \mathrm{~cm}$. In effect, a large wedge of sediment was extracted from the backfill mound (the base of which measured $225 \mathrm{~cm}$ ) so that an intact section wall was exposed. Excavation followed the stratigraphy in order to identify differential composition of anomalies such as those visible in Figure 5.

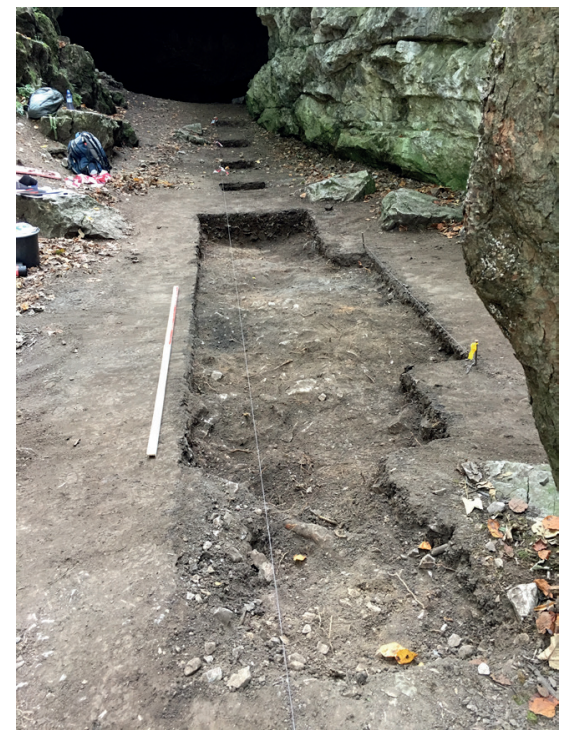

Fig. 7. Trench $A-B$ showing the location of the test pits. At this stage of the excavation the recent disturbed overburden had been removed, exposing in situ archaeologica deposit below. Photo by A. Way.

Obr. 7. Výkop $A-B$ slokalizací testovacích sond. $v$ této fázi výzkumu byla odstraněna vrstva recentně porušených sedimentů, čímž došlo k obnažení čímž došlo k obnažen sedimentů in situ. Foto A. Way.
Anecdotal reports suggest bones and artefacts have been found eroding out of this mound. Therefore, we excavated in arbitrary spits (excavation units) and processed all material using wet-sieving.

The second part of excavations targeted an area (close to the cave entrance) considered most likely to preserve in situ deposit. Excavation was guided by a review of data and figures recorded by Klíma (1962) and inspection of the cave floor and its immediate surroundings. A trench $3.5 \mathrm{~m}$ long by $0.5 \mathrm{~m}$ wide, and subsuming squares C13-C19, was excavated in an area previously excavated by Klíma's team in the 1950s (Fig. 6). Additional $0.5 \times 0.5 \mathrm{~m}$ test pits were excavated along the same axis as the trench towards the present entrance to the cave and include squares C1, C4, C7 and C10. This excavation trench, labelled A-B, located remnants of intact deposit (Fig. 7).

Excavated sediments were subjected to various geoarchaeological (sedimentological, micromorphological and chemical) analyses, also identification of large and micro vertebrate fauna, pollen analysis and collection of samples for radiocarbon and luminescence (OSL) dating. Samples of sediment were collected for DNA analyses to complement osteological analyses and to test for hominid presence. We will now examine these methods.

\section{Site formation and palaeoenvironmental datasets}

Seven micromorphology samples were collected and are currently being prepared and analysed at the Laboratory of Geological Processes, Institute of Geology, ASCR in Prague. Soil micromorphology has been used successfully, especially in areas with extreme changes in climatic regimes over time, in regolith science for over 70 years and its application to the investigation of archaeologically buried soils also has a long history (Macphail et al. 1990). Through the microscopic examination of thin sections of sediment, detailed information on sediment contents and formation history can be revealed, which are extremely useful when interpreting archaeological sites.

Sediment samples for micromorphological examination are impregnated with resin in vacuum, then sliced and thin sectioned to reveal the sediment structure and texture under 
Preliminary report of the 2019 excavation at Švédův Stůl Cave in the Moravian Karst • Nejman, L., Hughes, P., Sullivan, M., Wright, D.,

Way, A. M., Skopal, N., Mlejnek, O., Škrdla, P., Lisá, L., Kmošek, M., Nývltová Fišáková, M., Králík, M., Neruda, P., Nerudová, Z., Přichystal A.

Přehled výzkumů 61/1, 2020•11-19

a petrographic polarising light microscope. This analysis can provide information about aspects of the formation and composition of the sediment, the nature of the anthropogenic signature and post-depositional changes.

Bones of microfauna will also be analysed. Unlike many large fauna species, microfauna is known to be sensitive to the type of climate so the identification of species has the potential to contribute to palaeoenvironmental and palaeoclimate interpretations.

Pollen samples were also collected and are currently being analysed at the Department of Geological Sciences, Masaryk University. These data have the potential to provide another palaeoenvironmental dataset by revealing the types of plant communities that existed in the vicinity of the cave, and in the general area, during the time periods when the pollen was deposited in the cave.

\section{Sediment aDNA}

At Švédův Stůl, sediment DNA samples were collected during the excavation and sent for analysis to the Department of Evolutionary Genetics at the Max Planck Institute for Evolutionary Anthropology.

Sediment DNA is an exciting new technique where ancient DNA (aDNA) is extracted from sediments and identified to taxon level. Studies have shown that genetic signals of plants and animals can be retrieved from ancient sediments (e.g. Willerslev et al. 2003; Haile et al. 2007; Hebsgaard et al. 2009). It has also been shown that physical remains of organisms, or their ejecta, need to have been incorporated into the sediment for aDNA to be present, and aDNA in the sediment cannot be wind-borne (Haile et al. 2007). This procedure is routinely successful and faunal profiles can be built for sites, even in cases where actual macroscopic animal remains are absent. Sediment aDNA has been successfully extracted, identified and faunal sequences have been built for many dozens of sites in Eurasia (upcoming publication in the near future). This technique has already been successfully used at Pod Hradem cave in 2016 (publication in prep).

\section{Absolute dating}

Many animal bones and teeth were also recovered during the excavation. A few of these were selected for Electron Spin Resonance/U-series dating and Accelerator Mass Spectrometry (AMS) dating and are currently being analysed at the Research School of Earth Sciences, Australian National University, Canberra. These results will be the first absolute dating results obtained for this site. Sediment samples for Optically Stimulated Luminescence (OSL) dating were also collected and will be analysed at the University of Gliwice, Poland.

\section{Preliminary results and conclusions \\ Sediments from the spoil heap}

There is evidence for admixture (e.g. consistent presence of modern/ historic artefacts throughout all excavated sediments) in Trench C-D. Structural integrity may be suggested by visually distinct layers and lenses (see Fig. 5), also observation of conjoining historical artefacts within these lenses. Preliminary pXRF analyses (conducted by MK) supports this assessment, suggesting that bucket/wheelbarrow loads obtained during excavation of different layers was tipped/shovelled over the edge and were not always disguised through post-deposition mixing. Lenses vary between loads rich in fine sediments (presumably having undergone some sorting for bones/bone fragments, stone, other artefacts), loads of fine sediments that also contain historic artefacts including those apparently associated with the original excavations (dating to the 1890s and 1950s), and loads of broken limestone rubble with very little finer sedimentary matrix. Square C-D demonstrates why it is important not to ignore modern and historic materials within excavation databases. Presence/ quantities of these artefacts are critical for understanding integrity vs disturbance of cultural layers. No more information can be provided at this stage, awaiting the return of ITRAX, benchtop XRF and pXRF results.

Trench C-D contained 49 lithic artefacts confirming expectations about the value of spoil heap excavation. Raw materials represented include Cretaceous spongolitic chert, Jurassic Olomučany-type chert, Moravian Jurassic cherts (including atypical varieties of Krumlovský les-type and Stránská skála-type cherts, both probably from nearby gravels rather than primary outcrops), quartz, quartzite, limestone, radiolarite (probably from the White Carpathians outcrops), erratic flint (from current Czech-Polish boundary area), and Cracow-Czenstochowa Jurassic chert (probably a Neolithic intrusion). The last three raw materials are long-distance imports while the remainder are likely to have been sourced locally.

\section{Intact archaeological deposit below the base of Klíma's 1950s excavation}

Undisturbed deposits with archaeological materials and a rich faunal assemblage were located in most of the excavated pits comprising trench A-B (Fig. 8). These deposits were capped with up to $0.3 \mathrm{~m}$ of brown, disturbed overburden containing numerous fragments of plastic, glass and metal, as well as faunal remains derived from the spoil from the previous excavations. There was a sharp, slightly undulating break between this disturbed overburden and the underlying archaeological deposit.

The most extensive and deepest archaeological deposit (ca. $0.7 \mathrm{~m}$ thick) was in C16-C19 (Fig. 6); in C1, at the present cave entrance, it was $0.4 \mathrm{~m}$ thick (but bedrock was not reached) and elsewhere it was $<0.2 \mathrm{~m}$ thick. This artefact-bearing deposit consisted mainly of yellowish red to reddish yellow silt to very fine sand derived mainly from reworked loess which contained variable amounts of limestone rubble (pebble and cobble-sized) and limestone boulders. It contains very little clay, except at the base of the deposit where clay, moved down the profile by eluviation, or formed by the weathering of minerals at depth, has accumulated. Finely divided limestone is also present in most parts of the deposit. The degree to which the loess-like material blew into the sedimentary record directly or was washed in from the slopes above remains to be determined.

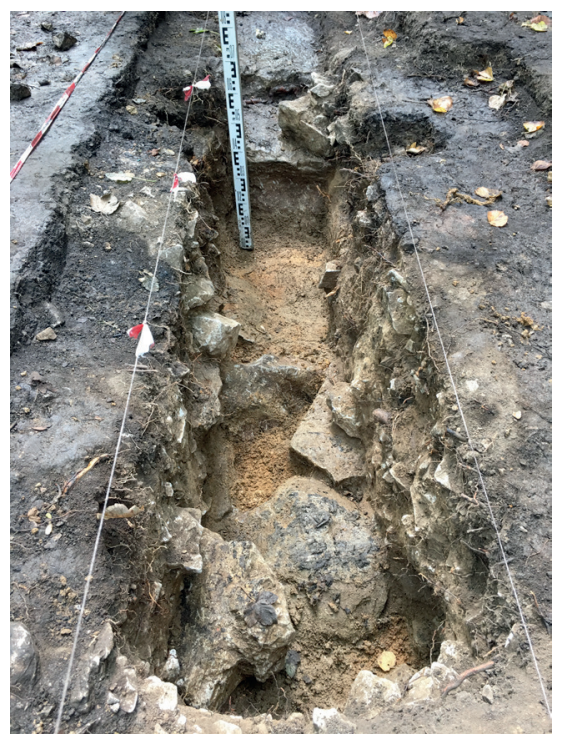

Fig. 8. Yellow sandy deposits captured in the base of squares $\mathrm{C} 13-\mathrm{C} 19$ representing Neogene marine transition preserved in the front part of the cave. These deposits have not been documented by researchers in any of the previous excavations in Švédův Stůl Cave. Photo by A. Way. Obr. 8. Žluté písčité sedimenty zachycené na bázi sektorů C13-C19 $\checkmark$ prední části jeskyně predstavujín neogénní mořské usazeniny, které nebyly doloženy během dřivějších výzkumů jeskyně švédův stůl. Foto A. Way. 
Preliminary report of the 2019 excavation at Švédův Stůl Cave in the Moravian Karst • Nejman, L., Hughes, P., Sullivan, M., Wright, D.,

Way, A. M., Skopal, N., Mlejnek, O., Škrdla, P., Lisá, L., Kmošek, M., Nývltová Fišáková, M., Králík, M., Neruda, P., Nerudová, Z., Přichystal A. Přehled výzkumů 61/1, 2020 • 11-19

Several generally small areas of disturbed fill were encountered during the excavation and these were removed and sieved separately from the adjacent apparently undisturbed deposits. Most were near the surface and were distinguished from the archaeological deposit by their darker, softer, more heterogeneous character. Most contained plastic, glass and metal debris. The largest of these was a pit extending into the western wall, as shown in Figure 6 and 8. At the base of the excavation in C13 a presumed animal burrow containing a bone from a domesticated cow was identified (likely dating to the Bronze Age as it is a small individual typical for this period). There were no modern contaminants in this feature.

No plastic, glass or metal debris was recovered from the remainder of the archaeological deposit. With a few younger exceptions, the 109 pieces of identified bone and shell recovered from this deposit were of animals known to have lived in this area during the late Pleistocene. Four of the exceptions were found in top 100-200 $\mathrm{mm}$ and could have been intrusive from the disturbed spoil above. Three were found at deeper levels, including a small fragment of Holocene mussel shell. We conclude that apart from those areas identified in the field as being disturbed, the bulk of the archaeological deposit is in situ.

Underlying the archaeological deposit was a highly distinctive sand deposit ranging downwards from slightly clayey silty fine sand to well-sorted, fine to medium sand with some very fine gravel. Sand grains were very well rounded and 'polished', predominantly composed of quartz with extremely little limestone. In character they resemble near-shore or beach sands more than fluvial sands. It is highly likely that ultimately they were derived from the Miocene marine sediments deposited when the sea transgressed over the Moravian Karst, but which have subsequently been extensively reworked and largely removed (Kadlec 2001a, 2001b). In the case of the sands in this deposit, their well sorted nature and lack of included limestone indicates that if they have been reworked, it has been from a very local source.

Seven knapped stone artefacts were recovered from the in situ sediments in the A-B trench. Cultural classification of these objects is not available at this stage, but more will be said after the results of absolute dating become available. The raw materials have all been identified as local and include quartz, quartzite and local cherts. This is consistent with Klíma's Mousterian levels he reports 40 Mousterian artefacts, most of which are local quartzites, local cherts and also some quartz and limestone (Klíma 1962, 51-53). He also reports eight Aurignacian artefacts (local cherts, erratic flint, radiolarite) and 64 Magdalenian artefacts (local cherts, radiolarite, erratic flint) (Klíma 1962, 54-55).

Bone and teeth samples have been submitted to the Radiocarbon Facility at the Research School of Earth Sciences at Australian National University for AMS dating. No charcoal was recovered in the in situ sediments during the 2019 excavation. Sediment samples for OSL dating were also collected and have been submitted to University of Gliwice for analysis.

A 'mild slope gradient' effect was detected along the A-B trench by pXRF scanning. For example, content of $\mathrm{Al}$ is lower in C15 (3.8\%) and higher in C19 (5.4\%). This same pattern applies to other elements $-\mathrm{Si}$, Fe and $\mathrm{Zr}$. The concentrations of Ca show an inverse pattern. It appears that as sediments become more recent upwards through the profile and towards the front of the trench (C19) Al, Si, Fe and Zr increase, whereas Ca decreases. This supports what we suspected earlier, that the more 'pure' loess which dominates towards the front of the trench would be higher in $\mathrm{Al}$ and heavier metal silicates and oxides (hence the higher $\mathrm{Al}, \mathrm{Si}, \mathrm{Fe}$ and $\mathrm{Zr}$ ) than the older sediments further back towards the present entrance of the cave, which are 'cave earths' formed by a mixture of the decomposition of limestone $\left(\mathrm{CaCO}_{3}\right)$ (which is very low in elements like $\mathrm{Al}, \mathrm{Si}, \mathrm{Fe}$ and $\mathrm{Zr}$, but high in $\mathrm{Ca})$ and loess.

Overall the pXRF preliminary results indicate the cave sediments are affected by calcium carbonate from blockfall rubble and the in situ sediments outside the present cave are predominantly non-calcareous loess with a relatively higher proportion of $\mathrm{Al}$ (from aluminium silicate molecules found in feldspars and clay minerals). The loess matrix is mainly homogenous and consists of small, weak to slightly firm peds which disperse readily on wet sieving to a mixture of silt and fine sand particles and some residual coarser sand-sized peds, which crush easily when squeezed in the hand. It is highly likely that, as at Pod Hradem (only $15 \mathrm{~km}$ to the north), the climate varied considerably during the depositional history of the sediments we have excavated (variably warm/humid, moderately cold, extremely cold - see Nejman et al. 2018) yet this is not reflected in variations in the field characteristics of this loess matrix, at least in C16-C19.

Osteological analyses of the faunal remains from intact layers indicate a number of extinct members of large fauna. Many of the bones from the intact sediments were taxonomically unidentifiable. Of the identifiable bones, the most common was cave bear, followed by horse, wolf, woolly rhinoceros, foxes, cave hyenas, aurochs/bison, cave lion, deer, mammoth, hare. In terms of MNI, cave bear is most common, followed by horse, rhinoceros, cave hyena, wolf. The remaining species are represented by one individual. The composition of the fauna suggests a colder climate.

Cave bear remains have been identified in each intact layer suggesting that all the cultural layers are older than $28 \mathrm{ka}$ (the minimum age for the extinction of this species). Results of absolute dating will give us a better idea of the age of these layers. A number of the animal bones have been tentatively identified as modified by humans. All of the bones are currently being assessed for human modification and the results will be published in an upcoming publication.

All of the preliminary findings presented in this article are subject to revision as the results of analyses become available and a more complete picture of the history of this cave is gradually built up.

\section{Acknowledgements}

We would like to thank the staff of PLA (CHKO) Administration Moravský kras, especially RNDr. Antonín Tůma and RNDr. Leoš Štefka for their support of this project. Authors Nejman, Škrdla, Kmošek and Nývltová Fišáková were supported with institutional support RVO: 68081758 - Czech Academy of Sciences, Institute of Archaeology, Brno. We would also like to thank Rear Admiral David John Campbell AM RAN (Rtd) and Michael Skopal for their generous private donations to the project.

Many thanks also to all the people who have participated in this research including the excavation volunteers. We also thank ANSTO for very practical advice and support with trial analyses of small sediment samples.

\section{References}

Binford, L. R. 1981: Bones: Ancient Men and Modern Myths. New York: Academic Press.

Chaplin, R. E. 1971: The study of animal bones from archaeological sites. London, New York: Seminar press.

Conard, N. J., Bolus, M., Dutkiewicz, E., Wolf, S. 2015: Eiszeitarchäologie auf der Schwäbischen Alb. Die Fundstellen im Ach und Lonetal und ihrer Umgebung. Tübingen Publications in Prehistory. Tübingen: Kerns Verlag. 
Preliminary report of the $\mathbf{2 0 1 9}$ excavation at Švédův Stůl Cave in the Moravian Karst • Nejman, L., Hughes, P., Sullivan, M., Wright, D., Way, A. M., Skopal, N., Mlejnek, O., Škrdla, P., Lisá, L., Kmošek, M., Nývltová Fišáková, M., Králík, M., Neruda, P., Nerudová, Z., Přichystal A. Přehled výzkumů 61/1,2020 • 11-19

Croudace, I. W., Rindby, A., Rothwell, R. G. 2006: ITRAX: description and evaluation of a new multi-function X-ray core scanner. In: R. G. Rothwell (ed.): New Techniques in Sediment Core Analysis. Geological Society, London, Special Publications, Volume 267. London: The Geological Society, 51-63.

Dutkiewicz, E. 2015: The Vogelherd Cave and the discovery of the earliest art - history, critics and new questions. In: N. Sans (ed.): Human Origin Sites and the World Heritage Convention in Eurasia, Heads 4, Volume I. World Heritage Papers 41. Paris, Ciudad de Mexico: United Nations Educational, Scientific and Cultural Organization, UNESCO Office in Mexico, 74-91.

France, D. L. 2009: Human and Nonhuman Bone Identification. A Color Atlas. Boca Raton (USA): CRC Press.

Habermeh1, K. H. 1985: Altersbestimmung bei Wild- und Pelztieren. Hamburg, Berlin: Verlag Paul Parey.

Haile, J., Holdaway, R., Oliver, K., Bunce, M., Gilbert, M. T. P., Nielsen, R., Munch, K., Ho, S. Y. W., Shapiro, B., Willerslev, E. 2007: Ancient DNA Chronology within Sediment Deposits: Are Paleobiological Reconstructions Possible and Is DNA Leaching a Factor? Molecular Biology and Evolution 24(4), 982-989.

Hebsgaard, M. B., Gilbert, M. T. P., Arneborg, J., Heyn, P., Allentoft, M. P., Bunce, M., Munch, K., Schweger, C., Willerslev E. 2009: 'The Farm Beneath the Sand' - an archaeological case study on ancient 'dirt' DNA. Antiquity 83(320), 430-444.

Hue, E. 1907: Ostéométrie des mammiféres. Musée Ostéologique. Étude de la Faune Quaternaire. Paris: Librairie C. Reinwald.

Kadlec, J., Hercman, H., Šroubek, P., Diehl, J. F., Granger, D. 2001a: Cenozoic history of the Moravian Karst cave systems, Czech Republic. In: M. A. Rasteiro (ed.): Speleology in the Third Millennium: Sustainable Development of Karst Environment. Proceedings of the 13th International Congress of Speleology, Brasilia, Brazil, 15-22 July 2001 [online]. Brasilia: Sociedade Brasileira de Espeleologia, 61-68. Available from: https://www.uis-speleo.org/ ics/13th_proceedings.pdf.

Kadlec, J., Hercman, H., Bene, V., Šroubek, P., Diehl, J. F., Granger, D. 2001b: Cenozoic history of the Moravian Karst (northern segment): cave sediments and karst morphology. Acta Musei Moraviae, Scientiae Geologicae 86, 111-160.

Klíma, B., 1962: Die archäologische Erforschung der Höhle „Švédův Stůl“ in Mähren. In: R. Musil (red.): Die archäologische Erforschung der Höhle „Švédiov Stůl“ 1953-1955. Anthropos 13, N. S. 5. Brno: Krajské nakladatelství v Brně, 7-96.

Koudelka, F. 1883: Der Schweden Sitz. Ein Beitrag zur Höhlenkunde Mährens. Mittheilungen der Section für Höhlenkunde des Oesterreichischen Touristen-Club II(1), 7-11.

Kurtén, B. 1958: Life and Death of the Pleistocene Cave Bear. Acta Zoologica Fennica 107, 1-74.

Kurtén, B. 1976: The Cave Bear Story, Life and Death of a Vanished Animal. New York: Columbia University Press.

Lavocat, R. (ed.) 1966: Atlas de Préhistoire III. Faunes et Flores Préhistoriques de l'Europe Occidentale. Paris: Éditions N. Boubée etc.

Lyman, R. L. 1994: Vertebrate Taphonomy. Cambridge: Cambridge University Press.

Macphail, R., Courty, M. A., Goldberg, P. 1990: Soil micromorphology in archaeology. Endeavour 14(4), 163-171.

Nejman, L., Lisá, L., Doláková, N., Horáček, I., Bajer, A., Novák, J., Wright, D., Sullivan, M., Wood, R., Gargett, R. H., Pacher, M., Sázelová, S., Nývltová Fišáková, M., Rohovec, J., Králík, M. 2018: Cave deposits as a sedimentary trap for the Marine Isotope Stage 3 environmental record. The case study of Pod Hradem, Czech Republic. Palaeogeography, Palaeoclimatology, Palaeoecology 497, 201-217.
Oliva, M. 2017: Př́iběh neandrtálské čelisti z jeskyně Švédův stůl v Moravském krasu. Acta Musei Moraviae, Scientiae sociales CII(1), 3-16.

Pales, L., Lambert, Ch. 1971: Atlas ostéologique pour servir á l'identification des Mammiféres du Quaternaire. Paris: Editions du centre national de la recherche scientifique.

Rzehak, A. 1906: Der Unterkiefer von Ochos. Ein Beitrag zur Kenntnis des altdiluvialen Menschen. Verhandlungen des Naturforschenden Vereines in Brünn XLIV (1905), 91-114.

Schmid, E. 1972: Atlas of animal bones. Amsterdam, London, New York: Elsevier publishing company.

Schmitz, R. W., Serre, D., Bonani, G., Feine, S., Hillgruber, F., Krainitzki, H., Pääbo, S., Smith, F. H. 2002: The Neandertal type site revisited: Interdisciplinary investigations of skeletal remains from the Neander Valley, Germany. Proceedings of the National Academy of Sciences of the United States of America 99(20), 13342-13347.

Valoch, K., Svoboda, J., Balák, I. 2002: Katalog moravských jeskyní s paleolitickými nálezy. In: J. Svoboda (ed.): Prehistorické jeskyně. Katalogy, dokumenty, studie. Dolnověstonické studie 7. Brno: Archeologický ústav AV ČR, Brno, 25-52.

Vaňura, J. 1963: Příspěvek k poznání jeskyně Švédův stůl v Moravském krasu. Československý kras 15, 59-68.

Vaňura, J. 1983: Ke stratigrafii jeskyně Švédův stůl v Moravském krasu. Časopis pro mineralogii a geologii 28(2), 187-196.

Willerslev, E., Hansen, A. J., Binladen, J., Brand, T. B., Gilbert, M. T. P., Shapiro, B., Bunce, M., Wiuf, C., Gilichinsky, D. A., Cooper, A. 2003: Diverse plant and animal genetic records from Holocene and Pleistocene sediments. Science 300, 791-795.

\section{Resumé}

Jeskyně Švédův stůl v Moravském krasu byla od dob prvního systematického výzkumu Martina Kř́iže v roce 1886 předmětem několika dalších badatelských aktivit. Hlavní představoval výzkum Bohuslava Klímy v letech 1953-1955. Poslední akce pak byla realizována $v$ roce 2019. Jejím cílem bylo ověření potenciálu lokality. Zkoumána byla výsypka sedimentů před jeskyní (výkopy $\mathrm{C}-\mathrm{D}$ ) a současně byla $\mathrm{v}$ témže místě položena série sond (výkopy A-B), jejichž cílem bylo ověření tvrzení B. Klímy, že plošina je $z$ archeologického pohledu již vyčerpaná, proto bylo překvapením, že pod výzkumem B. Klímy byly zachyceny zbytky intaktních sedimentů, které obsahovaly ojedinělé kamenné artefakty a četné pozůstatky fauny. Při výzkumu byly použity klasické výzkumné postupy, ale současně byly aplikovány další inovativní a experimentální sedimentologické a geoarcheologické metody. Př́́kladem může být nasazení pXRF, stolního ED-XRF a ITRAX přístrojů, cílených na možnost korelace sedimentů z výsypky (C-D) se stratifikovanými sedimenty ve výkopech (A-B). Tato metoda je založena na principu, že jednotlivé vrstvy mohou být geochemicky specifické v obsahu hlavního markerového prvku, vzácného stopového prvku nebo dvouprvkového poměru - např. vrstva, kde dominuje stropový opad může být obohacena vápníkem, naplavená vrstva může mít zvýšenou koncentraci železa, vápníku a hořčíku, nebo navátý material by mohl obsahovat zvýšenou koncentraci zinku, cínu, zirkonia, beryllia a hlavně křemíku.

Závěrem můžeme konstatovat, že všechny výkopy poskytly kosti zvírat a kamenné artefakty. Kosti, které bylo možné taxonomicky určit, poukazují na přítomnost pestré škály pleistocenních zvírrat jako jsou jeskynní medvědi, koně, vlci, nosorožci, lišky, hyeny, atd. Došlo jak k odebrání série vzorků pro geoarcheologické a paleoenvironmentální analýzy, tak k získání materiálu k určení datace. Zároveň byly odebrány vzorky sedimentů na aDNA analýzy. Všechny tyto vzorky jsou postupně zpracovávány a výsledky budou průběžně zveřejňovány v dalších výstupech z projektu. 
Preliminary report of the 2019 excavation at Švédův Stůl Cave in the Moravian Karst • Nejman, L., Hughes, P., Sullivan, M., Wright, D., Way, A. M., Skopal, N., Mlejnek, O., Škrdla, P., Lisá, L., Kmošek, M., Nývltová Fišáková, M., Králík, M., Neruda, P., Nerudová, Z., Přichystal A. Přehled výzkumů 61/1, 2020 • 11-19

\section{Contacts}

Ladislav Nejman

School of Philosophical and Historical Inquiry

University of Sydney

AU-2006 Sydney

lnejman81@gmail.com

\&

Archeologický ústav AV ČR, Brno, v. v. i.

Čechyňská 363/19

CZ-602 00 Brno

\section{Philip Hughes}

Department of Archaeology

Flinders University

AU-5001 Adelaide, South Australia

heh@bigpond.net.au

\section{Marjorie Sullivan}

School of Philosophical and Historical Inquiry

University of Sydney

AU-2006 Sydney

heh@bigpond.net.au

\section{Duncan Wright}

School of Archaeology and Anthropology

Banks Building, The Australian National University

44 Linnaeus Way

AU-0200 Canberra

duncan.wright@anu.edu.au

\section{Amy Mosig Way}

Australian Museum

6 College Street

AU-2010 Sydney

Amy.Way@austmus.gov.au

\&

School of Philosophical and Historical Inquiry

University of Sydney

AU-2006 Sydney

\section{Nicholas Skopal}

School of Archaeology and Anthropology

Australian National University

Banks Building, The Australian National University

44 Linnaeus Way

AU-0200 Canberra

nicholas.skopal@anu.edu.au

\section{Ondřej Mlejnek}

Archeologické centrum Olomouc

U Hradiska $42 / 6$

CZ-779 00 Olomouc

mlejnek.o@seznam.cz

\section{Petr Škrdla}

Archeologický ústav AV ČR, Brno, v. v. i.

Čechyňská 363/19

CZ-602 00 Brno

skrdla@arub.cz

\section{Lenka Lisá}

Geologický ústav AV ČR, v. v. i.

Rozvojová 269

CZ-165 00 Prague 6

lisa@gli.cas.cz

Matěj Kmošek

Archeologický ústav AV ČR, Brno, v. v. i.

Čechyňská 363/19

CZ-602 00 Brno

kmosek@arub.cz

\section{Miriam Nývltová Fišáková}

Archeologický ústav AV ČR, Brno, v. v. i.

Čechyňská 363/19

CZ-602 00 Brno

nyvltova@arub.cz

\section{Miroslav Králík}

Ústav antropologie, Př́rodovědecká fakulta Masarykova univerzita

Kotlářská 267

CZ-611 37 Brno

18313@muni.cz

\section{Petr Neruda}

Moravské zemské muzeum

Zelný trh 6

CZ-659 37 Brno

pneruda@mzm.cz

\section{Zdeňka Nerudová}

Moravské zemské muzeum

Zelný trh 6

CZ-659 37 Brno

znerudova@mzm.cz

\section{Antonín Přichystal}

Ústav geologický věd, Přírodovědecká fakulta Masarykova univerzita

Kotlářská 267/2

CZ-611 37 Brno

prichy@sci.muni.cz 
